\title{
KEJADIAN EKSTRAVASASI OBAT KEMOTERAPI PADA PASIEN KANKER
}

\author{
Marisa Junianti Manik \\ 1Dosen Fakultas Keperawatan dan Ilmu Kesehatan Universitas Pelita Harapan \\ e-mail: marisa.manik@uph.edu
}

\begin{abstract}
Chemotherapy is a cancer management with drugs. The complication that can be occurred is extravasation. The objective of this study was to analyze factors such as vein conditions, type of medications/ chemotherapeutic agents, volume of chemotherapeutic agents, and their correlation with chemotherapy drugs extravasation incidences. This study used cross sectional observational analytic design, with purposive sampling. The sample of this study was 70 cancer patients undergoing chemotherapy in hospitals. An inclusive criteria was patients with ages 18-65 in their first to fifth cycle of chemotherapy. The observation form was used as research instrument. The study showed that there were no correlation between vein conditions, type of medications/ chemotherapeutic agents, and volume of chemotherapeutic agents with extravasation. Most veins were still in good condition while undergoing chemotherapy. The length of time for administering chemotherapy were mostly $<24$ hours, which contributed for reducing risk for extravasation, although the type of medication used were irritants and vesicants, and with drugs volume of $100-1000 \mathrm{~mL}$. The incidences of extravasation that were immediately can be observed during chemotherapy occurred $7.14 \%$ of the time. It was possibly occurred by medical devices used, such as infusion pump that was facilitated the nurses in early anticipate drugs leakage outside the veins tissue. Nurses' roles also contributed to reduced extravasation risks. As conclusion, the results shown there were no correlation statistically; however there might be other contributing factors that need to be explored furthermore.
\end{abstract}

Keywords: extravasation, cancer chemotherapeutic agent

\section{ABSTRAK}

Kemoterapi merupakan salah satu cara penanganan kanker dengan menggunakan obat. Komplikasi yang bisa terjadi dari pemberian kemoterapi salah satunya adalah kejadian ekstravasasi. Tujuan penelitian ini untuk menganalisis faktor kondisi vena, lokasi vena, ukuran kanul, jenis obat, volume obat, lama paparan obat dan pemahaman pasien dan hubungannya dengan kejadian ekstravasasi. Penelitian menggunakan desain observasional analitik secara cross sectional dengan tehnik pengambilan sampel purposive. Sampel penelitian adalah pasien kanker yang sedang menjalani terapi kemoterapi di rumah sakit sebanyak 70 responden. Kriteria inklusi mencakup pasien dalam siklus kemoterapi kesatu sampai kelima dan berada dalam rentang usia 18 - 65 tahun. Instrumen penelitian menggunakan lembar observasi. Studi menunjukkan tidak ada hubungan faktor kondisi vena, lokasi vena, ukuran kanul, jenis obat, volume obat, lama paparan obat dan pemahaman pasien yang didapatkan dengan kejadian ekstravasasi obat kemoterapi. Sebagian besar kondisi vena responden masih dalam keadaan baik saat 
menjalani kemoterapi dan jangka waktu pemberian kemoterapi yang mayoritas <24 jam berkontribusi dalam penurunan risiko terjadinya kejadian ekstravasasi walaupun jenis obat yang didapatkan bersifat iritan dan vesikan serta volume obat kemoterapi sebanyak 100 $1000 \mathrm{ml}$. Kejadian ekstravasasi yang dapat diobservasi segera saat pemberian kemoterapi sekitar $7.14 \%$. Hal itu dapat disebabkan oleh penggunaan alat medis infuse pump, yang membantu perawat dalam mengantisipasi secara dini adanya kebocoran obat ke jaringan diluar pembuluh darah. Peran perawat yang baik dalam pemberian obat kemoterapi juga berkontribusi dalam penurunan angka ekstravasasi. Walaupun hasil menunjukkan tidak memiliki hubungan secara statistik namun adanya kejadian ekstravasasi menunjukkan bahwa ada faktor lain yang berhubungan dengan kejadian ekstravasasi yang perlu diteliti lebih lanjut.

Kata kunci: ekstravasasi, agen kemoterapi kanker

\section{PENDAHULUAN}

Saat ini prevalensi kejadian kanker di Indonesia maupun dunia berdasarkan data World Health Organization (WHO) tahun 2015 mengalami peningkatan yang signifikan. Dalam dua dekade mendatang diperkirakan jumlah kasus baru akan meningkat sekitar 70\%. Kanker juga merupakan salah satu penyebab kematian di seluruh dunia dengan angka sekitar 8.2 juta kematian pada tahun 2012 (WHO, 2015). Kemoterapi merupakan salah satu cara penanganan kanker dengan menggunakan obat. Kemoterapi sistemik memainkan peran penting dalam terapi kuratif untuk pasien dengan neoplasma hematologi dan beberapa jenis tumor pada tahap lanjut. Meskipun beberapa agent oral sudah dikembangkan baru-baru ini, kebanyakan agent anti kanker diberikan secara intravena. Komplikasi yang bisa terjadi dari pemberian kemoterapi adalah kejadian ekstravasasi yang terjadi sewaktu obat secara tidak sengaja masuk ke dalam jaringan di sekitar akses intravena pemberian obat kemoterapi. Insiden terjadinya ekstravasasi pada orang dewasa diperkirakan sekitar 0.01 sampai $6.9 \%$, namun hanya sedikit studi yang melaporkan insiden dengan data yang pasti (Sakaida, et. al., 2013). Menurut penelitian Mubarak pada tahun 2013, kejadian ekstravasasi di bangsal kemoterapi RSUD Dr. Sardjito Yogyakarta sebesar $12,7 \%$. Studi yang meneliti mengenai faktor risiko dan kejadian ekstravasasi obat kemoterapi sudah pernah dilakukan oleh Cicilia, Manik, M dan Florensa pada tahun 2014, namun hanya meneliti tiga faktor risiko yakni kondisi vena, lokasi vena dan jenis obat kemoterapi dan jumlah responden hanya 30 orang dan merupakan pasien kemoterapi siklus pertama dan kedua. Penelitian yang akan dilakukan ini lebih luas mencakup tujuh faktor risiko dan responden yang lebih banyak mencakup semua siklus kemoterapi yang dijalankan di rumah sakit. Insiden ekstravasasi tentu saja sangat diharapkan tidak terjadi. Pemberian obat kemoterapi harus aman dan efektif. Sebagai konsekuensinya, manajemen yang tepat sangat dibutuhkan untuk mencegah terjadinya kejadian ekstravasasi ini. Peran perawat dalam praktik pemberian kemoterapi yang aman dan efektif sangat penting. Perawat harus mampu melakukan upaya pencegahan, identifikasi, manajemen penanganan dan dokumentasi kejadian ekstravasasi akibat komplikasi kemoterapi. Perawat 
harus mengetahui bahwa obat kemoterapi tertentu memiliki sifat merusak jaringan dan dapat menyebabkan ulserasi yang menetap, nyeri dan progresif jika diberikan dengan tidak benar. Tingkat keparahan injuri juga dapat berhubungan dengan jenis obat. Faktor lainnya untuk kejadian ekstravasasi yaitu jenis dan ukuran alat/ kanula, lokasi akses vena, kondisi vena, jenis agent, lama jaringan terkena obat, volume/ jumlah obat kemoterapi yang digunakan dan kemampuan komunikasi pasien (Dougherty, 2011).

\section{METODE PENELITIAN}

Penelitian dilaksanakan di salah satu rumah sakit swasta yang berfokus pada perawatan kanker di Jakarta setelah mendapatkan persetujuan etik dari Komite Etik MRIN (Mochtar Riady Institute for Nanotechnology). Populasi penenelitan adalah pasien yang didiagnosa kanker dan sedang dalam masa pengobatan kemoterapi secara intravena di rumah sakit $X$. Penelitian ini menggunakan desain observasional analitik secara cross sectional dengan tehnik pengambilan sampel purposive. Kriteria inklusi mencakup pasien dalam siklus kemoterapi ke 1-5 dan berusia dari 18 - 65 tahun dan kriteria eksklusi pada penelitian ini adalah pasien yang mendapatkan kemoterapi melalui CVC. Pada penelitian ini jumlah variabel independen yang diteliti sebanyak 7 variabel sehingga jumlah sampel menjadi $7 \times 10$ yakni 70 orang. Instrumen penelitian yang digunakan untuk mengukur variabel penelitian adalah lembar observasi. Lembar observasi ini dikembangkan sendiri oleh peneliti sesuai variabel yang dianalisis dan merupakan pengembangan lembar observasi yang telah digunakan sebelumnya oleh Cicilia, Manik M., dan Florensa, M (2014) yang melakukan pengukuran tiga variabel dari tujuh variabel yang akan diteliti saat ini serta tetap mengikuti standar operasional prosedur pemberian obat kemoterapi yang ada di rumah sakit tersebut. Uji validitas dan reliabilitas telah dilakukan untuk lembar observasi yang digunakan dan juga telah dilakukan Uji Cohen Kappa untuk memastikan bahwa tim peneliti yang menggunakan lembar observasi dan mengobservasi variabel yang diteliti memiliki persepsi yang sama.

Pengolahan dan analisis data pada penelitian dengan desain observasional analitik dan tehnik pengambilan sampel purposive ini menggunakan analisis Chi-square. Uji ini dilakukan untuk data non parametrik untuk menguji hubungan antara variabel independen (faktor-faktor yang berhubungan dengan kejadian ekstravasasi) dan variabel dependen (kejadian ekstravasasi) berskala ordinal maupun nominal.

\section{HASIL DAN PEMBAHASAN}

Pada bab ini akan diuraikan hasil penelitian dan uji statistik serta pembahasan dari masing-masing faktor yang berhubungan dengan kejadian ekstravasi. Adapun hasil penelitian menunjukkan:

Tabel 4.1 Faktor kondisi vena

\begin{tabular}{lcc}
\hline \multicolumn{1}{c}{ Kondisi Vena } & Jumlah & $\%$ \\
\hline Baik & 51 & 72.85 \\
\hline Buruk & 19 & 27.15 \\
\hline Jumlah & 70 & 100 \\
\hline
\end{tabular}


Tabel 4.2 Faktor lokasi vena

\begin{tabular}{lcc}
\hline \multicolumn{1}{c}{ Kondisi Vena } & Jumlah & $\%$ \\
\hline Vena Sefalika & 31 & 44.28 \\
\hline Vena Antebrakialis & 7 & 10 \\
\hline Vena Metarcarpal & 30 & 42.86 \\
\hline Vena Sentral & 2 & 2.86 \\
\hline Jumlah & 70 & 100 \\
\hline
\end{tabular}

Tabel 4.3 Faktor ukuran kanula

\begin{tabular}{lcc}
\hline \multicolumn{1}{c}{ Ukuran Kanula } & Jumlah & $\%$ \\
\hline Sesuai & 54 & 77.14 \\
\hline Terlalu kecil/besar & 16 & 22.86 \\
\hline Jumlah & 70 & 100 \\
\hline
\end{tabular}

Tabel 4.4 Faktor jenis obat

\begin{tabular}{lcc}
\hline \multicolumn{1}{c}{ Jenis obat } & Jumlah & $\%$ \\
\hline Netral & 8 & 11.43 \\
\hline Iritan & 37 & 52.86 \\
\hline Vesikan & 25 & 35.71 \\
\hline Jumlah & 70 & 100 \\
\hline
\end{tabular}

Tabel 4.5 Faktor volume obat kemoterapi

\begin{tabular}{lcc}
\hline \multicolumn{1}{c}{ Volume obat } & Jumlah & $\%$ \\
\hline $0-100 \mathrm{ml}$ & 1 & 1.43 \\
\hline $101-500 \mathrm{ml}$ & 34 & 48.57 \\
\hline $501-1000 \mathrm{ml}$ & 27 & 38.57 \\
\hline$>1000 \mathrm{ml}$ & 8 & 11.43 \\
\hline Jumlah & 70 & 100 \\
\hline
\end{tabular}

Tabel 4.6 Faktor lama paparan obat kemoterapi

\begin{tabular}{lcc}
\hline \multicolumn{1}{c}{ Lama Paparan } & Jumlah & $\%$ \\
\hline$<24$ jam & 61 & 87.14 \\
\hline $1-7$ hari & 8 & 11.43 \\
\hline$>7$ hari & 1 & 1.43 \\
\hline Jumlah & 70 & 100 \\
\hline
\end{tabular}

Tabel 4.7 Faktor pemahaman pasien mengenai ekstravasasi

\begin{tabular}{lcc}
\hline \multicolumn{1}{c}{ Pemahaman pasien } & Jumlah & $\%$ \\
\hline Paham & 63 & 90 \\
\hline Tidak paham & 7 & 10 \\
\hline Jumlah & 70 & 100 \\
\hline
\end{tabular}


Tabel 4.8 Kejadian Ekstravasasi

\begin{tabular}{lcc}
\hline \multicolumn{1}{c}{ Kejadian Ekstravasasi } & Jumlah & $\%$ \\
\hline Ya & 5 & 7.14 \\
\hline Tidak & 65 & 92.86 \\
\hline Jumlah & 70 & 100 \\
\hline
\end{tabular}

Tabel 4.9 Hubungan faktor -faktor risiko dengan kejadian ekstravasasi obat kemoterapi

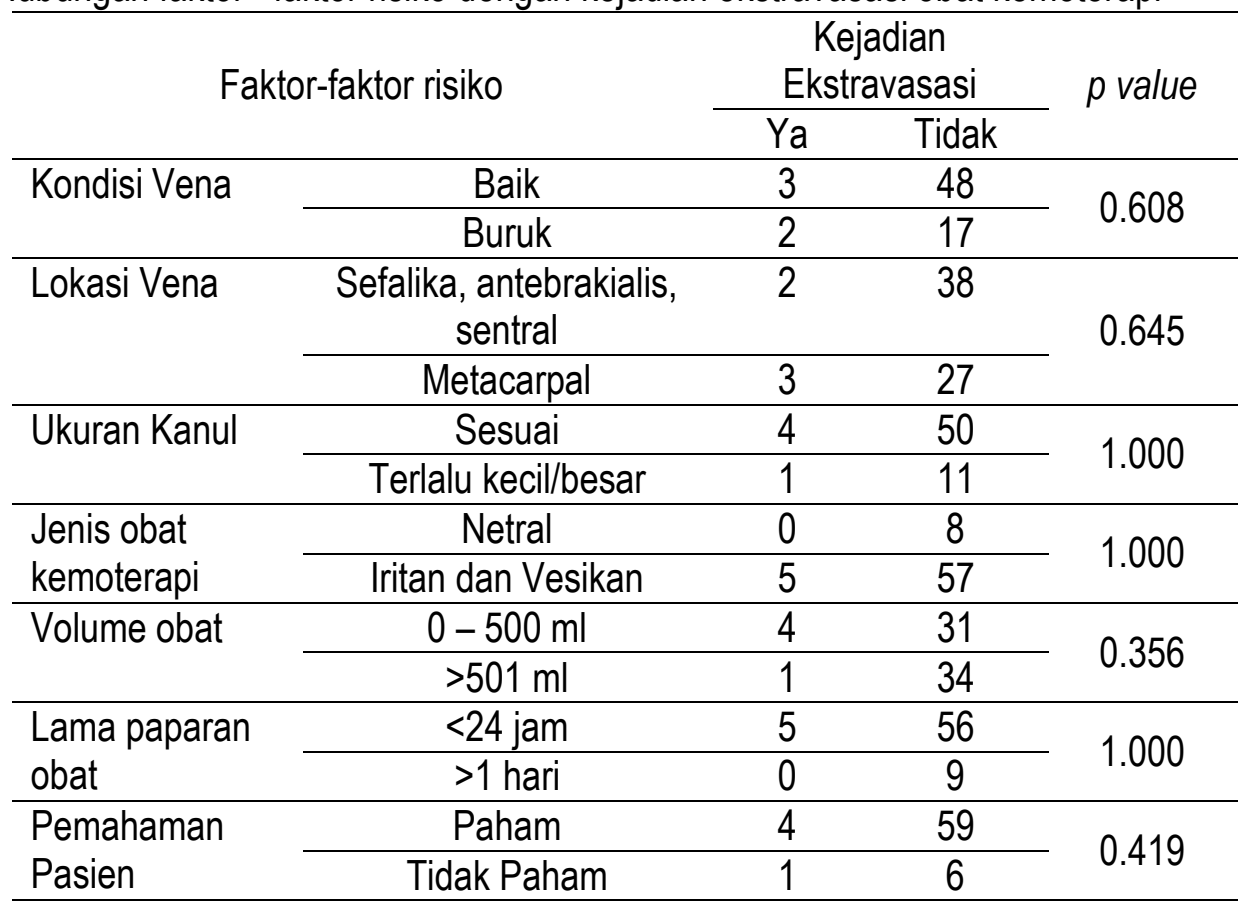

Penelitian ini menunjukkan bahwa tidak ada hubungan antara faktor risiko kondisi vena dengan kejadian ekstravasasi obat kemoterapi. Menurut Boschi \& Elena (2012) salah satu faktor risiko yang menyebabkan ekstravasasi obat kemoterapi pada vena perifer adalah kondisi vena yang kecil, dan/ atau rapuh. Kemungkinan alasan yang dapat dijelaskan mengenai tidak ada hubungannya antara faktor risiko kondisi vena dengan kejadian ekstravasasi karena pada sampel ditemukan kondisi vena mayoritas masih dalam keadaan baik dan belum banyak terpapar obat kemoterapi. Hal ini didukung dengan data responden yang melakukan kemoterapi lebih banyak pada siklus pertama dan kedua sehingga vena yang ditemukan merupakan vena yang masih layak dipakai dan belum rapuh serta tidak keras.

Berdasarkan nilai $p<0,200$, maka dapat dinyatakan bahwa secara statistik, tidak ada hubungan antara faktor risiko lokasi vena dengan kejadian ekstravasasi. Studi menurut Boschi \& Elena (2012) menyatakan bahwa salah satu cara untuk mencegah terjadinya ekstravasasi adalah dengan mencegah pemilihan vena yang berada dalam area tekukan (fleksi) dan vena pada lengan dengan lymphedema atau kerusakan neurologi. Pada penelitian ini tidak ditemukannya hubungan faktor risiko lokasi vena dengan kejadian 
ekstravasasi karena lokasi terbanyak yang menajdi pilihan akses oleh perawat adalah vena sefalika, antebrakialis dan vena sentral. Selain itu perawat yang akan melakukan kemoterapi sebelumnya sudah memberikan penjelasan tentang lokasi vena yang akan digunakan, sehingga pasien mengerti dan kooperatif, serta pasien dapat meminimalisir pergerakan dari tangan yang terpasang infus kemoterapi.

Dari penelitian yang dilakukan di lapangan, tidak terdapat hubungan jenis obat dengan kejadian ekstraavasasi obat kemoterapi, hal ini berbeda dengan yang diungkapkan di literature. Menurut penelitian Boschi \& Elena (2014), pemberian obat kemoterapi jenis obat vesikan sebaiknya diberikan melalui akses vena sentral, karena jenis obat vesikan dapat menyebabkan ekstravasasi obat kemoterapi bila diberikan melalui akses vena perifer yang kecil, Sebaiknya bila diberikan melalui vena perifer pergunakan akses vena perifer yang besar, elastis dan tidak banyak memanipulasi pergerakan.

Ukuran kanula yang digunakan dalam pemberian obat kemoterapi merupakan salah satu faktor risiko terjadinya extravasasi (Gonzalez, 2013). Oleh karena itu, kanula plastik yang digunakan harus sebisa mungkin merupakan ukuran terkecil dan harus sesuai dengan ukuran vena pasien. Hasil studi ini menunjukkan tidak terdapat hubungan ukuran kanula dengan kejadian ekstravasasi obat kemoterapi. Hal ini dikarenakan karena $77.14 \%$ ukuran kanula yang digunakan sesuai dengan ukuran vena yang akan digunakan sebagai akses pemberian kemoterapi.

Obat kemoterapi tertentu memiliki kandungan yang dapat merusak jaringan dan dapat menyebabkan ulserasi yang progresif, menetap dan sangat nyeri jika diberikan dengan tidak tepat (Oestreicher, 2007). Pada penelitian ini penggunaan obat kemoterapi $88.57 \%$ merupakan agen yang bersifat iritan dan vesikan sehingga meningkatkan risiko terjadinya ekstravasasi. Dari kejadian ekstravasasi dalam penelitian ini keseluruhannya merupakan obat kemoterapi yang bersifat iritan dan vesikan tersebut. Walaupun secara statistik menunjukkan tidak ada hubungan jenis obat kemoterapi ini dengan kejadian ekstravasasi, namun secara klinis hal ini tentu saja tetap berpengaruh. Sejalan dengan pemikiran bahwa jenis obat merupakan faktor risiko terjadinya ekstravasasi, maka semakin banyak jumlah/ volume cairan obat yang didapatkan oleh pasien tentu saja meningkatkan pula risiko terjadinya ekstravasasi (Sauerland, et al, 2006). Pada penelitian ini jumlah responden yang menerima volume obat kurang dari $500 \mathrm{ml}$ dan yang mendapatkan lebih dari $500 \mathrm{ml}$ memiliki persentase yang hamper sama. Namun dari kejadian ekstravasasi yang terjadi, $80 \%$ mendapatkan volume obat kurang dari $500 \mathrm{ml}$. Hal ini menunjukkan bahwa tidak terdapat hubungan volume obat dengan kejadian ekstravasasi obat kemoterapi.

Lama paparan vena terhadap obat kemoterapi yang didapatkan merupakan faktor risiko lain yang menyebabkan ekstravasasi. Semakin lama kontak maka risiko kerusakan jaringan akan meningkat (Sauerland, et al, 2006). Namun pada penelitian ini lama paparan vena terhadap obat kemoterapi 87,1\% adalah kurang dari 24 jam. Sehingga dari uji statistik ditemukan bahwa tidak terdapat hubungan lama paparan obat kemoterapi dengan kejadian ekstravasasi obat kemoterapi. 
Boschi \& Elena (2012) dan Gonzalez (2013) merekomendasikan bahwa untuk mencegah terjadinya ekstravasasi obat kemoterapi maka pasien sebaiknya diberikan edukasi mengenai risiko terjadinya ekstravasasi dan diminta untuk melaporkan sensasi nyeri yang mungkin muncul atau rasa terbakar yang dirasakan sesegera mungkin kepada perawat. Pada penelitian ini $90 \%$ responden paham akan tanda dan gejala ekstravasasi. Hasil uji statistik pada penelitian ini menunjukkan bahwa tidak terdapat hubungan pemahaman pasien dengan kejadian ekstravasasi obat kemoterapi namun secara klinis pemahaman pasien ini sangat membantu dalam mencegah terjadinya kejadian ekstravasasi. Seperti halnya pendapat Oestreicher, 2007 bahwa edukasi dapat membantu meminimalkan risiko ekstravasasi.

\section{KESIMPULAN DAN SARAN}

Dalam penelitian ini angka kejadian ekstravasasi hanya $7,14 \%$. Secara statistik hasil ini menunjukkan tidak ada hubungan faktor-faktor kondisi vena, lokasi vena, ukuran kanula, jenis obat, volume obat, lama paparan obat dan pemahaman pasien. Pemberian kemoterapi yang aman dan pencegahan ekstravasasi merupakan tanggungjawab bersama para team yang terlibat dalam pemberian obat kemoterapi kepada pasien (Kreidieh, Hiba \& Nagi, 2016). Edukasi pada pasien mengenai risiko dan maifestasi yang bisa muncul merupakan hal yang penting. Pencegahan ekstravasasi obat kemoterapi merupakan indikator kualitas keperawatan. Oleh karenanya diharapkan untuk meningkatkan dan mempertahankan kinerja perawat dalam melakukan tindakan keperawatan yang sesuai dengan standar operasional prosedur sebagai upaya untuk meningkatkan patient safety dan peningkatan mutu keperawatan yang berkontribusi aktif untuk penilaian akreditasi rumah sakit.

\section{DAFTAR PUSTAKA}

American Cancer Society. (2013). Chemoterapy What it is, how it helps. www.cancer.org

Cicilia, Manik, M., \& Florensa, M. (2014). Faktor risiko dan kejadian ekstravasasi obat kemoterapi. Nursing Current Journal, 2(2), 4652

Dahlan, M. Sopiyudin. (2010). Besar sampel dan cara pengambilan sampel dalam penelitian kedokteran dan kesehatan. Jakarta: Salemba Medika

Dougherty, L and Catherine O. (2011). Advanced practice in the management of extravasation. Cancer nursing practice. 10 (5) 16 $-22$

Gonzalez, T. (2013). Chemoterapy extravasations: prevention, identification, management and documentation. Clinical Journal of Oncology Nursing. Volume 17, Number 1, page 61-66

Kreidieh F, Hiba M, Nagi S. (2016). Overview, prevention and management of chemotherapy extravasation. World Journal of Clinical Oncology. 7(1): 87-97

Lewis, S. (2010). Medical Surgical Nursing: Assessment and management of clinical problem. $8^{\text {th }}$ Edition. Mosby: Elsevier Science

Marelli, TM. (2008). Buku saku dokumentasi keperawatan. Jakarta: EGC

Miller, G. (2008). Pencegahan dan pengobatan penyakit kanker. Jakarta: Prestasi Pustaka 
Mouridsen, et.al. (2007). Treatment of anthracycline extravasation with Savene (dexrazoxane). Annals of Oncology 18(3): 546-550

Mubarak, C. (2013). Faktor risiko yang mempengaruhi kejadian extravasasi kemoterapi intravena perifer di RSUP Dr. Sardjito Yogyakarta Tahun 2011-2013. http://etd.ugm.ac.id/index.php?mo $\mathrm{d}=$ penelitian_detail\&sub=Penelitia nDetail\&act=view\&typ=html\&buku_ id $=63348 \&$ obyek_id $=4$

Oestreicher, P. (2007). Can you recognize the risk factors for the vesicant extravasation?. ONS Connect. 22, 1, 22 - 23

Otto. SE. (2005). Keperawatan onkologi. Jakarta: EGC

Polit \& Beck. (2006). Essentials of nursing research: methods, appraisal, and utilization. $6^{\text {th }}$ ed. Philadelphia: Lippincott Williams \& Wilkins.
Sakaida, E. et. al. (2014). Incidence, risk factors and treatment outcomes of extravasation of cytotoxic agents in an outpatient chemotherapy clinic. Japanese Journal of Clinical Oncology. 44(2) 168 - 171

Sauerland C, Engelking C, Wickham R, Corbi D (2006). Vesicant extravasation part I: mechanisms, pathogenesis, and nursing care to reduce risk. Oncol Nurs Forum. 33(6) 1134-41

Schulmeister, L. (2007). Managing vesicant extravasations. The Oncologist. 13, $284-288$

World Health Organization. (2015). Media centre: Cancer. http://www.who.int/mediacentre/fac tsheets/fs297/en/\#

Yulia, T. (2012). Gambaran tingkat pengetahuan pasien tentang pengobatan kemoterapi di rumah sakit kanker Dharmais. http://lontar.ui.ac.id 